\title{
Model Persediaan pada Produk yang Mendekati Masa Kadaluwarsa: Mempertimbangkan Diskon Penjualan dan Retur
}

\author{
Laila Nafisah $^{1 *}$, Wellem Sally ${ }^{1}$, Puryani $^{1}$
}

\begin{abstract}
Most products are sold in Mirota Campus Supermarkets have perishable nature. One of the strategies undertaken in product sales is by providing discounts on products approaching expiry date. The closer to the expiration date, then the discounts given per unit will increase. Allows product pemasoks can in returns with the terms and conditions agreed. In this paper, developed a model multi-item inventory for a product that has a shelf-life of taking into account discounts and product returns. Completion of the model is done with optimization approach based on parameters that influence in this model. Numerical examples are given at the end of this paper to illustrate the model settlement algorithms.
\end{abstract}

Keywords: EOQ, perishable product, discount of sale, backorder, return.

\section{Pendahuluan}

Persediaan merupakan sumber daya yang menganggur, sehingga keberadaannya dapat dipandang sebagai pemborosan dan ini berarti beban bagi suatu unit usaha dalam bentuk biaya yang lebih tinggi (Bahagia [1]). Salah satu produk yang sering menyebabkan pemborosan dalam persediaan adalah produk yang memiliki sifat kadaluwarsa. Oleh karena itu, keberadaannya perlu diminimasi.

Mirota Kampus Swalayan adalah sebuah retailer yang menjual berbagai macam produk kebutuhan sehari-hari. Salah satu bagian yang terpenting di swalayan ini adalah bagian produk makanan dan minuman. Sebagai pengelola, pihak Mirota Kampus menaruh perhatian khusus dan pengawasan yang baik pada bagian ini karena menyangkut masa kadaluwarsa produk. Kualitas, kesehatan, dan keselamatan konsumen menjadi dasar pelayanan yang sangat penting untuk diperhatikan bagi pihak pengelola dalam menyediakan produk kepada konsumen. Jika hal ini diabaikan, maka sangat membahayakan konsumen dan berakibat kerugian bagi pengelola.

Dalam menjalankan usahanya, Mirota Kampus Swalayan menjalin kerja sama dengan beberapa pemasok. Bentuk kontrak kerja sama yang disepakati dengan pemasok pun bermacam-macam, diantaranya adalah pemasok mengijinkan pihak Mirota Mirota Kampus untuk melakukan retur pada produk yang mendekati tanggal kadaluwarsa.

\footnotetext{
1 Fakultas Teknologi Industri, Program Studi Teknik Industri, Universitas Pembangunan Nasional "Veteran" Yogyakarta, J. Babarsari 2 Tambakbayan Yogyakarta 55281, Indonesia. Email: lailanafisah71@gmail.com

* Penulis korespondensi
}

Produk yang diretur akan diganti/dikirim pada periode pemesanan berikutnya. Selain itu, untuk meningkatkan penjualan dan menghindari kerugian yang lebih besar lagi, mereka bersepakat menetapkan suatu strategi dengan cara memberikan diskon kepada konsumen terhadap produk yang mendekati tanggal kadaluwarsa dengan tingkatan-tingkatan tertentu. Semakin mendekati tanggal kadaluwarsa maka diskon per unit yang diberikan kepada konsumen akan semakin besar.

Semakin banyak produk yang disediakan, maka akan semakin banyak modal yang tertanam yang tidak dapat dipergunakan untuk keperluan lain yang lebih menguntungkan dan semakin besar pula resiko produk yang kadaluwarsa. Semakin sedikit produk yang tersedia, maka kemungkinan terjadinya kekurangan persediaan akan semakin besar. Akibatnya semakin besar pula terjadinya kehilangan kesempatan untuk mendapatkan keuntungan. Oleh karenanya pengendalian persediaan terhadap produk yang memiliki masa kadaluwarsa ini sangat perlu dilakukan untuk menghindari kerugiankerugian yang timbul yang lebih besar lagi akibat kadaluwarsanya produk.

Penelitian mengenai model pengendalian persediaan untuk produk kadaluwarsa secara intensif telah banyak dilakukan oleh beberapa peneliti. Indrianti, et al. [2] telah melakukan penelitian tentang masalah persediaan bahan baku yang mempertimbangkan faktor kadaluwarsa. Model ini mempertimbangkan bahan baku yang telah kedaluwarsa masih bisa dijual dengan harga yang lebih rendah. Nafisah, et al. [3] mengembangkan model persediaan deterministik untuk produk yang memiliki masa kadaluwarsa dan produk kadaluwarsa tidak dapat dijual kembali tetapi produk dapat dikembalikan ke pemasok (diretur) sebelum tanggal kadaluwarsa 
tiba. Produk yang diretur akan diganti/dikirim pada periode pemesanan berikutnya. Kekurangan persediaan diperbolehkan dan diatasi dengan backorder, dimana jumlah yang diatasi secara backorder tersebut sama dengan jumlah produk yang kadaluwarsa. Adapun dalam Singh et al. [4] telah dikembangkan model persediaan untuk produk kadaluwarsa dimana laju permintaannya konstan tetapi berbeda-beda untuk selang waktu tertentu. Karmakar et al. [5] telah mengkaji beberapa model persediaan yang mempertimbangkan adanya kekurangan persediaan akibat produk telah mengalami kadaluwarsa dengan pola permintaan yang berbedabeda.

Penelitian tentang persediaan dengan mempertimbangkan faktor kadaluwarsa produk dengan mempertimbangkan diskon yang diberikan oleh pemasok juga telah dilakukan oleh Prasetyo, et al. [6,7]. Dimana dalam kedua penelitian tersebut kasus yang diangkat masih single item. Limansyah et al. [8] mengembangkan model persediaan untuk kasus multi item dengan pertimbangan prosentase kadaluwarsa dan unit diskon.

Jaya, et al. [9] menjelaskan bahwa banyak penelitian berikutnya berkembang dengan memperhatikan diskon harga, hal ini disebabkan oleh perlunya pemberian diskon harga untuk meningkatkan penjualan bagi barang yang akan kadaluwarsa. Bramorski [10] dalam observasinya menemukan bahwa 98\% respondennya selalu memperhatikan waktu kadaluwarsa. Pada penelitian tersebut juga menyebutkan bahwa dengan meningkatkan nilai diskon pada produk yang mendekati tanggal kadaluwarsa, responden akan memiki keinginan yang lebih besar untuk membeli produkproduk tersebut. Oleh sebab itu faktor diskon sangat perlu dipertimbangkan dalam penyusunan satu kebijakan.

Pada penelitian-penelitian terdahulu, umumnya diskon yang dipertimbangkan adalah diskon yang diberikan oleh pihak pemasok kepada pengecer. Padahal pada kenyataannya banyak juga pengecer yang memberlakukan diskon terhadap produk yang dijualnya yang mendekati kadaluwarsa. Widyadana et al. [11] telah melakukan penelitian mengenai model persediaan untuk produk yang memiliki masa kadaluwarsa dengan menerapkan strategi penurunan harga (markdown policy) untuk meningkatkan tingkat permintaan, dimana penurunan harga setiap periodenya berbeda-beda (price dependent demand).

Berdasarkan fenomena permasalahan yang dihadapi Mirota Kampus tersebut, maka pada penelitian ini akan dikembangkan model persediaan yang mempertimbangkan faktor pemberian diskon penjualan kepada konsumen atas produk yang mendekati kadaluwarsa dengan tingkatan-tingkatan tertentu. Semakin mendekati tanggal kadaluwarsa maka diskon per unit yang diberikan akan semakin besar, sehingga dengan adanya diskon tersebut permintaannya menjadi berbeda-beda. Selain itu dipertimbangkan pula adanya faktor pengembalian produk. Adanya diskon penjualan per unit ini akan menyebabkan munculnya biaya expired treatment sebagai konsekuensi biaya yang muncul akibat hilangnya sebagian margin keuntungan dari adanya diskon yang diberlakukan.

Susunan pada makalah ini terbagi dalam empat bagian. Bagian pertama pendahuluan, bagian kedua adalah pengembangan model, bagian ketiga contoh numerik dan terakhir adalah kesimpulan dari hasil penelitian yang telah dilakukan

\section{Metode Penelitian}

Notasi parameter yang digunakan dalam model ini sebagai berikut:

$T C$ : total biaya persediaan per tahun

$P C$ : total biaya pembelian per tahun

$O C$ : total biaya pesan per tahun

$H C$ : total biaya simpan per tahun

$E C$ : total biaya kadaluwarsa per tahun

$S C$ : total biaya kekurangan persediaan per tahun

$R C$ : total biaya retur per tahun

ETC : total expired treatment per tahun

$t_{1}$ : waktu ketika diskon penjualan tahap pertama dimulai

$t_{2}$ : waktu ketika diskon penjualan tahap kedua dimulai

$t_{3} \quad$ : waktu ketika diskon penjualan tahap ketiga dimulai

$T$ : panjang siklus dari produk datang hingga waktu kadaluwarsa

$\theta \quad$ : laju kadaluwarsa, $0<\theta<1$

$P \quad$ : harga beli per unit

$h$ : biaya simpan

$A \quad$ : biaya pesan per sekali pesan

$\pi \quad$ : biaya backorder

$A_{r} \quad$ : biaya retur per sekali retur

$a \quad$ : harga jual per unit

$R \quad$ : biaya retur per unit

I : rate of interest

$M \quad$ : profit margin

$X$ : besar diskon pada tahap perlakuan pertama, persen (\%)

$Y$ : besar diskon pada tahap perlakuan kedua, persen (\%)

$Z$ : besar diskon pada tahap perlakuan ketiga, persen (\%)

$x \quad$ : persentase profit margin yang hilang pada tahap pertama perlakuan diskon 
$y \quad$ : persentase profit margin yang hilang pada tahap kedua perlakuan diskon

$z \quad$ : persentase profit margin yang hilang pada tahap ketiga perlakuan diskon

$M L_{X}$ : profit margin yang hilang per unit setelah dikenakan diskon sebesar $X \%$

$M L_{Y}$ : profit margin yang hilang per unit setelah dikenakan diskon sebesar $Y \%$

$M L_{Z}$ : profit margin yang hilang per unit setelah dikenakan diskon sebesar $Z \%$

$E T C_{X}$ : biaya expired treatment setelah dikenakan diskon sebesar $X \%$

$E T C_{Y}$ : biaya expired treatment setelah dikenakan diskon sebesar $Y \%$

$E T C_{Z}$ : biaya expired treatment setelah dikenakan diskon sebesar $Z \%$

Adapun notasi variabel yang digunakan dalam model ini sebagai berikut:

$D(t)$ : laju permintaan

$I(t)$ : level persediaan pada saat $0 \leq t \leq T$

$T_{r}$ : saat ketika retur dilakukan

$Q$ : kuantitas pemesanan

$Q_{r} \quad$ : kuantitas produk yang di retur

$T_{r}^{*} \quad$ : waktu retur optimal

$Q^{*} \quad$ : kuantitas pemesanan optimal

\section{Pengembangan Model}

Penelitian ini merupakan pengembangan model persediaan yang berbasis studi kasus di Mirota Kampus Swalayan. Model dasar yang digunakan dalam pengembangan model di sini adalah modelnya Nafisah et al [3]. Dimana dalam model Nafisah et al. [3] telah dikembangkan model persediaan deterministik, single item yang mempertimbangkan adanya faktor kadaluwarsa dan pengembalian produk. Adapun pada penelitian ini akan dikembang- kan model persediaan deterministik yang mempertimbangkan kadaluwarsa dan retur, dimana laju permintaannya konstan tetapi berbeda-beda untuk selang waktu tertentu akibat dari adanya diskon penjualan secara bertahap sebelum produk mengalami kadaluwarsa. Model yang diusulkan ini diharapkan dapat menghasilkan kebijakan pengendalian persediaan yang tepat dalam menentukan berapa kuantitas pemesanan produk yang optimal, berapa kuantitas produk yang mendekati kadaluwarsa yang dapat di retur dan kapan retur dilakukan agar dapat meminimasi total biaya persediaan.

Asumsi dasar yang digunakan dalam penelitian ini adalah bahwa laju permintaan, $D(t)$, konstan tetapi berbeda-beda yang merupakan fungsi terhadap waktu, dimana:

$$
D(t)= \begin{cases}B_{0} & \text { untuk } 0 \leq t \leq t_{1} \\ B_{1} & \text { untuk } t_{1} \leq t \leq t_{2} \\ B_{2} & \text { untuk } t_{2} \leq t \leq t_{3} \\ B_{3} & \text { untuk } t_{3} \leq t \leq T_{r} \\ B_{4} & \text { untuk } T_{r} \leq t \leq T\end{cases}
$$

Berdasarkan Gambar 1 tersebut, terlihat bahwa level persediaan pada model yang direpresentasikan merupakan trapezoidal type demand rate.

Pada saat $t=0$, pesanan produk datang sebesar $Q$ sehingga level persediaan mencapai titik maksimum. Kemudian dengan berjalannya waktu, maka level persediaan mulai berkurang dengan adanya permintaan yang datang, laju permintaan tersebut konstan tetapi berbeda-beda untuk setiap periodenya yang mengikuti persamaan (1). Perbedaan laju permintaan tersebut disebabkan karena adanya diskon penjualan secara bertahap yang diberikan perusahaan kepada konsumen untuk meningkatkan tingkat penjualan produk yang mendekati kadaluwarsa.

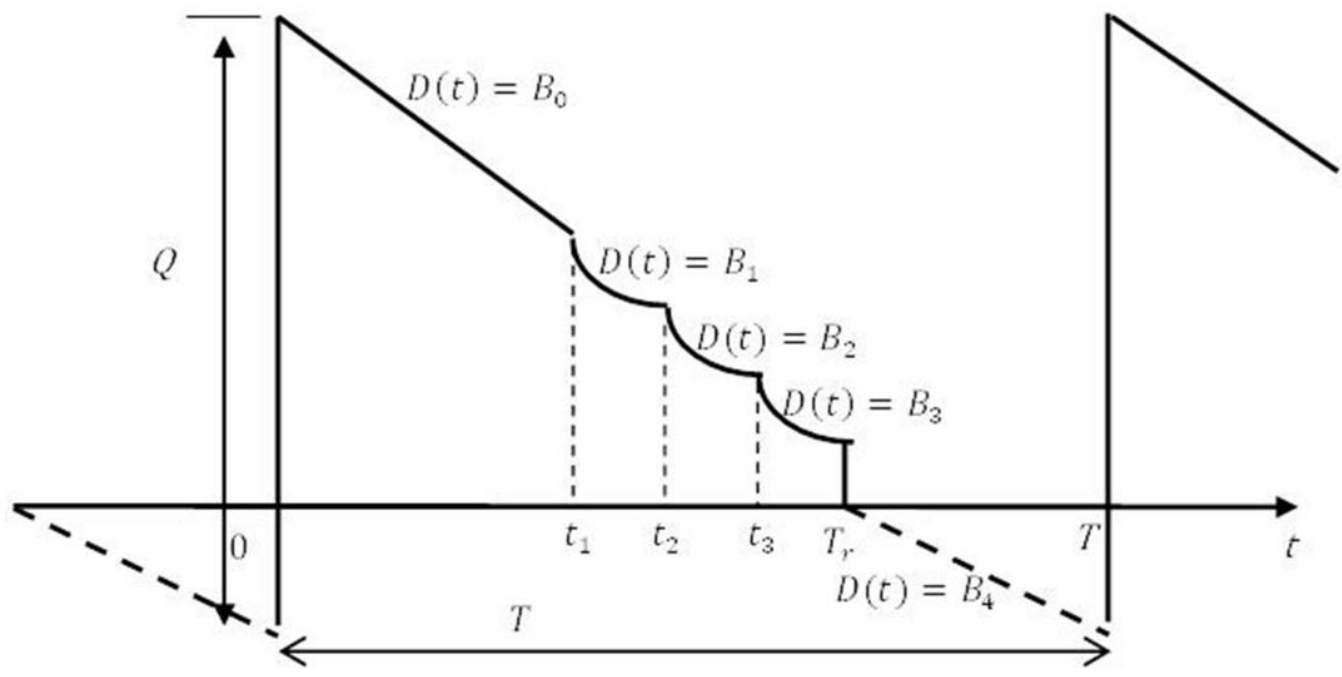

Gambar 1. Representasi level persediaan selama satu siklus T 
Pada saat $t=T_{r}$ terjadi retur untuk semua produk yang mendekati kadaluwarsa. Pada saat retur dilakukan, level persediaan mencapai titik nol atau $I\left(T_{r}\right)=0$. Stockout terjadi selama interval $\left[T_{r}, T\right]$ dan diatasi full backorder karena produk yang diretur seluruhnya akan dikirim kembali oleh pemasok secara bersamaan dengan pengiriman pesanan perusahaan pada periode berikutnya.

Berdasarkan notasi dan asumsi di atas, maka secara umum level persediaan selama $0 \leq t \leq T$ dapat dijelaskan sebagai;

$\frac{d I(t)}{d t}+\theta I(t)=-D(t)$

sehingga berdasarkan persamaan (1), akan diperoleh beberapa level persediaan sebagai berikut:

$\frac{d I(t)}{d t}+\theta I(t)=-B_{0} \quad$ untuk $\quad 0 \leq t \leq t_{1}$

$\frac{d I(t)}{d t}+\theta I(t)=-B_{1} \quad$ untuk $\quad t_{1} \leq t \leq t_{2}$

$\frac{d I(t)}{d t}+\theta I(t)=-B_{2} \quad$ untuk $\quad t_{2} \leq t \leq t_{3}$

$\frac{d I(t)}{d t}+\theta I(t)=-B_{3} \quad$ untuk $\quad t_{3} \leq t \leq T_{r}$

$\frac{d I(t)}{d t}+\theta I(t)=-B_{4} \quad$ untuk $\quad T_{r} \leq t \leq T$

Untuk mendeferensialkan persamaan (3) sampai (7), mengikuti cara sebagai berikut:

Pada $t=T_{r}$ level persediaan $I(t)=0$, maka berdasarkan persamaan (7) diperoleh;

$\frac{d I(t)}{d t}=-B_{4} ; I(t)=\int_{T_{r}}^{T}-B_{4} d t$

$I(t)=B_{4}\left(T_{r}-T\right)$ untuk $T_{r} \leq t \leq T$

Persamaan umum (Jayashree [12]):

$\frac{d y}{d x}+P y=Q$

$y \cdot e^{\int P d x}=\int Q \cdot e^{\int P d x} d x+c$

Pada $t_{3} \leq t \leq T_{r}$ berdasarkan persamaan (6):

$\frac{d I(t)}{d t}+\theta I(t)=-B_{3}$

$I(t) \cdot e^{\int \theta d t}=\int-B_{3} \cdot e^{\int \theta d t} d t+C_{3}$

$I(t) \cdot e^{\theta t}=-\int_{B_{3}} B_{3} \cdot e^{\theta t} d t+C_{3}$

$I(t) \cdot e^{\theta t}=-\frac{B_{3}}{\theta} \cdot e^{\theta t}+C_{3}$

$I(t)=-\frac{B_{3}}{\theta}+C_{3} \cdot e^{-\theta t}$

Pada saat $t=T_{r}$, level persediaan $I\left(T_{r}\right)=0$, maka dari persamaan (11) diperoleh;

$I\left(T_{r}\right)=-\frac{B_{3}}{\theta}+C_{3} \cdot e^{-\theta T_{r}}$

$0=-\frac{B_{3}}{\theta}+C_{3} \cdot e^{-\theta T_{r}}$

$C_{3}=\frac{B_{3}}{\theta} \cdot e^{\theta T_{r}}$

Persamaan (12) disubstitusikan ke persamaan (11), diperoleh;

$I(t)=\frac{B_{3}}{\theta}\left(e^{\theta\left(T_{r}-t\right)}-1\right)$ untuk $t_{3} \leq t \leq T_{r}$
Dengan cara yang sama akan diperoleh level persediaan sebagai berikut

$I(t)=\frac{B_{2}}{\theta}\left(e^{\theta\left(t_{3}-t\right)}-1\right)+\frac{B_{3}}{\theta}\left(e^{\theta T_{r}}-e^{\theta t_{3}}\right) e^{-\theta t}$

untuk $t_{2} \leq t \leq t_{3}$

$I(t)=\frac{B_{1}}{\theta}\left(e^{\theta\left(t_{2}-t\right)}-1\right)+\left\{\frac{B_{2}}{\theta}\left(e^{\theta t_{3}}-e^{\theta t_{2}}\right)+\right.$

$\left.\frac{B_{3}}{\theta}\left(e^{\theta T_{r}}-e^{\theta t_{3}}\right)\right\} e^{-\theta t} \quad$ untuk $t_{1} \leq t \leq t_{2}$

$I(t)=\frac{B_{0}}{\theta}\left(e^{\theta\left(t_{1}-t\right)}-1\right)+\left\{\frac{B_{1}}{\theta}\left(e^{\theta t_{2}}-e^{\theta t_{1}}\right)+\right.$

$\left.\frac{B_{2}}{\theta}\left(e^{\theta t_{3}}-e^{\theta t_{2}}\right)+\frac{B_{3}}{\theta}\left(e^{\theta T_{r}}-e^{\theta t_{3}}\right)\right\} e^{-\theta t}$

untuk $0 \leq t \leq t_{1}$

Pada saat $t=0, I(t=0)=Q-B_{4}\left(T_{r}-T\right)$, maka berdasarkan persamaan (16) diperoleh;

$Q=\frac{B_{0}}{\theta}\left(e^{\theta t_{1}}-1\right)+\frac{B_{1}}{\theta}\left(e^{\theta t_{2}}-e^{\theta t_{1}}\right)+\frac{B_{2}}{\theta}\left(e^{\theta t_{3}}-\right.$

$\left.e^{\theta t_{2}}\right)+\frac{B_{3}}{\theta}\left(e^{\theta T_{r}}-e^{\theta t_{3}}\right)+B_{4}\left(T_{r}-T\right)$

Total jumlah persediaan selama interval $\left[0, T_{r}\right]$ :

$m=\int_{0}^{T_{r}} I(t) d t$

$=\int_{0}^{t_{1}}\left\{\frac{B_{0}}{\theta}\left(e^{\theta\left(t_{1}-t\right)}-1\right)+\left\{\frac{B_{1}}{\theta}\left(e^{\theta t_{2}}-e^{\theta t_{1}}\right)+\right.\right.$

$\left.\left.\frac{B_{2}}{\theta}\left(e^{\theta t_{3}}-e^{\theta t_{2}}\right)+\frac{B_{3}}{\theta}\left(e^{\theta T_{r}}-e^{\theta t_{3}}\right)\right\} e^{-\theta t}\right\} d t$

$+\int_{t_{1}}^{t_{2}}\left\{\frac{B_{1}}{\theta}\left(e^{\theta\left(t_{2}-t\right)}-1\right)+\left\{\frac{B_{2}}{\theta}\left(e^{\theta t_{3}}-e^{\theta t_{2}}\right)+\right.\right.$

$\left.\left.\frac{B_{3}}{\theta}\left(e^{\theta T_{r}}-e^{\theta t_{3}}\right)\right\} e^{-\theta t}\right\} d t$

$+\int_{t_{2}}^{t_{3}}\left\{\frac{B_{2}}{\theta}\left(e^{\theta\left(t_{3}-t\right)}-1\right)+\frac{B_{3}}{\theta}\left(e^{\theta T_{r}}-e^{\theta t_{3}}\right) e^{-\theta t}\right\} d t+$

$\int_{t_{3}}^{T_{r}}\left\{\frac{B_{3}}{\theta}\left(e^{\theta\left(T_{r}-t\right)}-1\right)\right\} d t$

$m=\frac{B_{0}}{\theta^{2}}\left(e^{\theta t_{1}}-1\right)+\frac{B_{1}}{\theta^{2}}\left(e^{\theta t_{2}}-e^{\theta t_{1}}\right)+\frac{B_{2}}{\theta^{2}}\left(e^{\theta t_{3}}-\right.$

$\left.e^{\theta t_{2}}\right)+\frac{B_{3}}{\theta^{2}}\left(e^{\theta T_{r}}-e^{\theta t_{3}}\right)-\frac{B_{3} \cdot T_{r}}{\theta}$

Total jumlah stockout akibat produk diretur selama interval $\left[T_{r}, T\right]$ :

$S(x)=-\int_{T_{r}}^{T} I(t) d t$

$S(x)=-\int_{T_{r}}^{T}\left\{B_{4}\left(T_{r}-T\right)\right\} d t$

$S(x)=B_{4}\left(T_{r}-T\right)^{2}$

Fungsi tujuan dari model yang dikembangkan adalah minimasi total biaya persediaan per tahun (TC) yang terdiri dari biaya pembelian per tahun $(P C)$, biaya pesan per tahun $(O C)$, biaya simpan per tahun (HC), biaya kekurangan persediaan per tahun (SC), biaya expired treatment per tahun (ETC), dan biaya retur per tahun $(R C)$.

\section{Biaya Pembelian per Tahun}

$P C=P . D$

\section{Biaya Pesan per Tahun}

$O C=\frac{A}{T}$ 


\section{Biaya Simpan per Tahun}

$$
\begin{aligned}
& H C=\frac{h}{2 T}\left\{\frac{B_{0}}{\theta^{2}}\left(e^{\theta t_{1}}-1\right)+\frac{B_{1}}{\theta^{2}}\left(e^{\theta t_{2}}-e^{\theta t_{1}}\right)+\right. \\
& \left.\frac{B_{2}}{\theta^{2}}\left(e^{\theta t_{3}}-e^{\theta t_{2}}\right)+\frac{B_{3}}{\theta^{2}}\left(e^{\theta T_{r}}-e^{\theta t_{3}}\right)-\frac{B_{3} \cdot T_{r}}{\theta}\right\}
\end{aligned}
$$

\section{Biaya Kekurangan Persediaan per Tahun}

Biaya kekurangan persediaan (stockout) adalah biaya yang harus dikeluarkan karena terjadinya kekurangan produk akibat dari adanya produk yang di retur. Diasumsikan konsumen loyal, sehingga konsumen mau menunggu untuk dipenuhi permintaannya pada periode yang akan datang (stockout diatasi secara backorder).

Biaya stockout per tahun merupakan perkalian antara biaya backorder /unit/tahun dengan rata-rata jumlah yang diretur selama setahun.

$S C=\frac{\pi B_{4}}{2 T}\left(T_{r}-T\right)^{2}$

\section{Biaya Expired Treatment per Tahun}

Biaya expired treatment adalah biaya yang hilang akibat dari adanya perlakuan diskon secara bertahap terhadap seluruh produk yang mendekati kadaluwarsa selama satu tahun.

Biaya expired treatment setahun merupakan perkalian antara rata-rata kuantitas yang dikenakan diskon per siklus dengan hilangnya profit margin setelah diberlakukan diskon dan jumlah siklus per tahun.

Profit margin yang hilang per siklus = (profit margin) $\mathrm{x}$ (persentase profit margin yang hilang setelah didiskon).

Harga jual $=$ harga beli + profit margin

$a=P+M$

sehingga, profit margin:

$M=a-P$

Asumsi:

Profit margin hilang pada diskon tahap pertama perlakuan diskon setelah didiskon sebesar $x \%$ dari profit margin pada harga normal

Profit margin hilang pada diskon tahap kedua perlakuan diskon setelah didiskon sebesar $y \%$ dari profit margin total pada harga normal

Profit margin hilang pada diskon tahap ketiga perlakuan diskon setelah didiskon sebesar $z \%$ dari profit margin total pada harga normal, maka profit margin yang hilang per unit setelah diberlakukan diskon berdasarkan perlakuan diskon yang digunakan yaitu:
Untuk diskon pada tahap pertama

$$
M L_{X}=(a-P) \cdot x \%
$$

Untuk diskon pada tahap kedua

$$
M L_{Y}=(a-P) \cdot y \%
$$

Untuk diskon pada tahap ketiga

$$
M L_{z}=(a-P) \cdot z \%
$$

Nilai $x, y, z$ ditentukan berdasarkan persamaan:

$x=\frac{M L_{x}}{M}, y=\frac{M L_{X}}{M}, z=\frac{M L_{Z}}{M}$

sedangkan nilai $X, Y, Z$ ditentukan berdasarkan persamaan:

$X=\frac{M L_{X}}{a}, Y=\frac{M L_{Y}}{a}, Z=\frac{M L_{Z}}{a}$

dimana besarnya $x<y<z$ dan $X<Y<Z$

Sehingga biaya expired treatment per tahun:

$E T C=E T C_{X}+E T C_{Y}+E T C_{Z}$

Jika terdapat kondisi bahwa:

1. Tahap perlakuan pertama dilakukan diskon sebesar $X \%$ dari harga jual produk, terjadi pada saat $t_{1} \leq t \leq t_{2}$, maka biaya expired treatment per tahun:

$$
\begin{aligned}
& E T C_{X}=\frac{M L_{X}}{2 T}\left\{\int _ { t _ { 1 } } ^ { t _ { 2 } } \left\{\frac{B_{1}}{\theta}\left(e^{\theta\left(t_{2}-t\right)}-1\right)+\right.\right. \\
& \left.\left.\left\{\frac{B_{2}}{\theta}\left(e^{\theta t_{3}}-e^{\theta t_{2}}\right)+\frac{B_{3}}{\theta}\left(e^{\theta T_{r}}-e^{\theta t_{3}}\right)\right\} e^{-\theta t}\right\} d t\right\} \\
& E T C_{X}=\frac{M L_{X}}{2 T}\left\{\frac{B_{1}}{\theta^{2}}\left(e^{\theta\left(t_{2}-t_{1}\right)}-1\right)-\frac{B_{1}}{\theta}\left(t_{2}-t_{1}\right)-\right. \\
& \frac{B_{2}}{\theta^{2}}\left(e^{-\theta t_{2}}-e^{-\theta t_{1}}\right)\left\{\left(e^{\theta t_{3}}-e^{\theta t_{2}}\right)+\left(e^{\theta T_{r}}-\right.\right. \\
& \left.\left.\left.e^{\theta t_{3}}\right)\right\}\right\}
\end{aligned}
$$

2. Tahap perlakuan kedua dilakukan diskon sebesar $Y \%$ dari harga jual produk, terjadi pada saat $t_{2} \leq t \leq t_{3}$, maka biaya expired treatment per tahun:

$$
\begin{aligned}
& E T C_{Y}=\frac{M L_{Y}}{2 T}\left\{\int _ { t _ { 2 } } ^ { t _ { 3 } } \left\{\frac{B_{2}}{\theta}\left(e^{\theta\left(t_{3}-t\right)}-1\right)+\frac{B_{3}}{\theta}\left(e^{\theta T_{r}}-\right.\right.\right. \\
& \left.\left.\left.e^{\theta t_{3}}\right) e^{-\theta t}\right\} d t\right\} \\
& E T C_{Y}=\frac{M L_{Y}}{2 T}\left\{\frac{B_{2}}{\theta^{2}}\left(e^{\theta\left(t_{3}-t_{2}\right)}-1\right)-\frac{B_{2}}{\theta}\left(t_{3}-t_{2}\right)-\right. \\
& \left.\frac{B_{3}}{\theta^{2}}\left(e^{-\theta t_{3}}-e^{-\theta t_{2}}\right)\left(e^{\theta T_{r}}-e^{\theta t_{3}}\right)\right\}
\end{aligned}
$$

3. Tahap perlakuan ketiga dilakukan diskon sebesar $Z \%$ dari harga jual produk, terjadi pada saat $t_{3} \leq t \leq T_{r}$, maka biaya expired treatment per tahun:

$$
\begin{aligned}
& E T C_{Z}=\frac{M L_{Z}}{2 T} \int_{t_{3}}^{T_{r}}\left\{\frac{B_{3}}{\theta}\left(e^{\theta\left(T_{r}-t\right)}-1\right)\right\} d t \\
& E T C_{Z}=\frac{M L_{Z}}{2 T}\left\{\frac{B_{3}}{\theta^{2}}\left(e^{\theta\left(T_{r}-t_{3}\right)}-1\right)-\frac{B_{3}}{\theta}\left(T_{r}-t_{3}\right)\right\}
\end{aligned}
$$

Total biaya expired treatment per tahun:

$$
\begin{aligned}
& E T C=\frac{M L_{X}}{2 T}\left\{\frac{B_{1}}{\theta^{2}}\left(e^{\theta\left(t_{2}-t_{1}\right)}-1\right)-\frac{B_{1}}{\theta}\left(t_{2}-t_{1}\right)-\right. \\
& \left.\frac{B_{2}}{\theta^{2}}\left(e^{-\theta t_{2}}-e^{-\theta t_{1}}\right)\left\{\left(e^{\theta t_{3}}-e^{\theta t_{2}}\right)+\left(e^{\theta T_{r}}-e^{\theta t_{3}}\right)\right\}\right\} \\
& +\frac{M L_{Y}}{2 T}\left\{\frac{B_{2}}{\theta^{2}}\left(e^{\theta\left(t_{3}-t_{2}\right)}-1\right)-\frac{B_{2}}{\theta}\left(t_{3}-t_{2}\right)-\right. \\
& \left.\frac{B_{3}}{\theta^{2}}\left(e^{-\theta t_{3}}-e^{-\theta t_{2}}\right)\left(e^{\theta T_{r}}-e^{\theta t_{3}}\right)\right\}+ \\
& \frac{M L_{Z}}{2 T}\left\{\frac{B_{3}}{\theta^{2}}\left(e^{\theta\left(T_{r}-t_{3}\right)}-1\right)-\frac{B_{3}}{\theta}\left(T_{r}-t_{3}\right)\right\}
\end{aligned}
$$




\section{Biaya Retur per Tahun}

Biaya retur adalah biaya yang dikeluarkan akibat melakukan retur. Diasumsikan bahwa produk yang diretur akan diganti oleh pemasok dengan produk yang sama dalam jumlah dan jenis dengan masa kadaluwarsa lebih panjang.

Biaya retur terdiri dari biaya per sekali retur dan biaya per unit produk yang harus ditanggung pihak Mirota akibat melakukan retur.

Pihak pemasok hanya menerima retur untuk produk yang mendekati kadaluwarsa sekurang-kurangnya selama $\left(T-T_{r}\right)$ dari tanggal kadaluwarsa produk tersebut.

Biaya retur merupakan penjumlahan dari biaya retur per sekali retur dan konsekuensi biaya yang harus ditanggung pihak Mirota akibat melakukan retur sejumlah $Q_{r}$.

Besarnya rata-rata konsekuensi biaya per tahun yang harus ditanggung akibat melakukan retur adalah biaya retur per unit dikalikan dengan ratarata jumlah yang diretur per siklus dan banyaknya siklus dalam setahun;

$C_{r}=\frac{R}{2}\left\{\frac{B_{0}}{\theta}\left(e^{\theta t_{1}}-1\right)+\frac{B_{1}}{\theta}\left(e^{\theta t_{2}}-e^{\theta t_{1}}\right)+\right.$ $\frac{B_{2}}{\theta}\left(e^{\theta t_{3}}-e^{\theta t_{2}}\right)+\frac{B_{3}}{\theta}\left(e^{\theta T_{r}}-e^{\theta t_{3}}\right)-B_{4}\left(T_{r}-T\right)$

$\left.-B_{0} \cdot t_{1}-B_{1}\left(t_{2}-t_{1}\right)-B_{2}\left(t_{3}-t_{2}\right)-B_{3}\left(T_{r}-t_{3}\right)\right\}$

\section{Total Biaya Retur per Tahun:}

$R C=\frac{1}{T}\left\{A_{r}+\frac{R}{2}\left\{\frac{B_{0}}{\theta}\left(e^{\theta t_{1}}-1\right)+\frac{B_{1}}{\theta}\left(e^{\theta t_{2}}-e^{\theta t_{1}}\right)+\right.\right.$ $\frac{B_{2}}{\theta}\left(e^{\theta t_{3}}-e^{\theta t_{2}}\right)+\frac{B_{3}}{\theta}\left(e^{\theta T_{r}}-e^{\theta t_{3}}\right)-B_{4}\left(T_{r}-T\right)$ $\left.\left.-B_{0} \cdot t_{1}-B_{1}\left(t_{2}-t_{1}\right)-B_{2}\left(t_{3}-t_{2}\right)-B_{3}\left(T_{r}-t_{3}\right)\right\}\right\}$

\section{Total Biaya Persediaan per Tahun:}

$$
\begin{aligned}
& T C= P . D+\frac{A}{T}+\frac{h}{2 T}\left\{\frac{B_{0}}{\theta^{2}}\left(e^{\theta t_{1}}-1\right)+\frac{B_{1}}{\theta^{2}}\left(e^{\theta t_{2}}-\right.\right. \\
&\left.e^{\theta t_{1}}\right)+\left.\frac{B_{2}}{\theta^{2}}\left(e^{\theta t_{3}}-e^{\theta t_{2}}\right)+\frac{B_{3}}{\theta^{2}}\left(e^{\theta T_{r}}-e^{\theta t_{3}}\right)-\frac{B_{3} \cdot T_{r}}{\theta}\right\} \\
&+\frac{\pi B_{4}}{2 T}\left(T_{r}-T\right)^{2} \\
&+\frac{M L_{X}}{2 T}\left\{\frac{B_{1}}{\theta^{2}}\left(e^{\theta\left(t_{2}-t_{1}\right)}-1\right)-\frac{B_{1}}{\theta}\left(t_{2}-t_{1}\right)-\right. \\
& \frac{B_{2}}{\theta^{2}}\left(e^{-\theta t_{2}}-e^{-\theta t_{1}}\right)\left\{\left(e^{\theta t_{3}}-e^{\theta t_{2}}\right)+\right. \\
&\left.\left.\left(e^{\theta T_{r}}-e^{\theta t_{3}}\right)\right\}\right\} \\
&+\frac{M L_{Y}}{2 T}\left\{\frac{B_{2}}{\theta^{2}}\left(e^{\theta\left(t_{3}-t_{2}\right)}-1\right)-\frac{B_{2}}{\theta}\left(t_{3}-t_{2}\right)-\right. \\
&\left.\frac{B_{3}}{\theta^{2}}\left(e^{-\theta t_{3}}-e^{-\theta t_{2}}\right)\left(e^{\theta T_{r}}-e^{\theta t_{3}}\right)\right\} \\
&+\frac{M L_{Z}}{2 T}\left\{\frac{B_{3}}{\theta^{2}}\left(e^{\theta\left(T_{r}-t_{3}\right)}-1\right)-\frac{B_{3}}{\theta}\left(T_{r}-t_{3}\right)\right\} \\
&+\frac{1}{T}\left\{A_{r}+\frac{R B_{4}}{2}\left(T_{r}-T\right)^{2}\right\} \\
&
\end{aligned}
$$

Untuk menentukan kapan saat retur dilakukan $\left(T_{r}\right.$ optimal) dalam rangka meminimasi total biaya persediaan per tahun, maka persamaan (37) dideferensialkan sedemikian rupa sehingga $\frac{\partial T C}{\partial T_{r}}=0$ sehingga diperoleh;

$$
\begin{aligned}
\frac{\partial T C}{\partial T_{r}}= & \frac{h \cdot B_{3}}{\theta}\left(e^{\theta T_{r}}-1\right)+\pi \cdot B_{4}\left(T_{r}-T\right) \\
& +\frac{M L_{X} \cdot B_{2}}{\theta}\left(e^{-\theta t_{2}}-e^{-\theta t_{1}}\right) e^{\theta T_{r}} \\
& +\frac{M L_{Y} \cdot B_{3}}{\theta}\left(e^{-\theta t_{3}}-e^{-\theta t_{2}}\right) e^{\theta T_{r}}+ \\
& \frac{M L_{Z} \cdot B_{3}}{\theta}\left(e^{\theta\left(T_{r}-t_{3}\right)}-1\right)+R B_{4}\left(T_{r}-T\right)=0
\end{aligned}
$$

Berdasarkan persamaan (38), terlihat bahwa untuk mencari nilai $T_{r}$ yang optimal ternyata masih mengandung variabel $T_{r}$.

Dimisalkan

$$
\begin{aligned}
& f\left(T_{r}\right)=\frac{h \cdot B_{3}}{\theta}\left(e^{\theta T_{r}}-1\right)+\pi \cdot B_{4}\left(T_{r}-T\right)+ \\
& \frac{M L_{X} \cdot B_{2}}{\theta}\left(e^{-\theta t_{2}}-e^{-\theta t_{1}}\right) e^{\theta T_{r}} \\
& \quad+\frac{M L_{Y} \cdot B_{3}}{\theta}\left(e^{-\theta t_{3}}-e^{-\theta t_{2}}\right) e^{\theta T_{r}}+ \\
& \quad \frac{M L_{Z} \cdot B_{3}}{\theta}\left(e^{\theta\left(T_{r}-t_{3}\right)}-1\right)++R B_{4}\left(T_{r}-T\right)
\end{aligned}
$$

Pada $T_{r}=t_{3}, f\left(t_{3}\right)<0$ dan pada $T_{r}=T, f(T)>$ 0 , sedangkan $\frac{\partial f\left(T_{r}\right)}{\partial T_{r}}>0$.

$T_{r}$ optimal yang meminimasi TC diperoleh jika dan hanya jika $t_{3}<T_{r}^{*}$

Besarnya kuantitas pemesanan yang optimal, $Q^{*}$, dinyatakan sebagai

$Q^{*}=I(t=0)+S(x)$

Untuk mencari $T_{r}^{*}$, persamaan (38) dapat disederhanakan sebagai berikut;

$$
\begin{aligned}
T_{r}= & \frac{1}{\theta \cdot B_{4}(\pi+R)}\left\{h B_{3}+\theta B_{4} T(\pi+R)+M L_{Z} B_{3}\right\} \\
& -\frac{1}{\theta \cdot B_{4}(\pi+R)}\left\{h B_{3}+M L_{X} B_{2}\left(e^{-\theta t_{2}}-e^{-\theta t_{1}}\right)+\right. \\
& \left.M L_{Y} B_{3}\left(e^{-\theta t_{3}}-e^{-\theta t_{2}}\right)+M L_{Z} B_{3} e^{-\theta t_{3}}\right\} e^{\theta T_{r}}
\end{aligned}
$$

Jika,

$$
\begin{aligned}
& E=\frac{1}{\theta \cdot B_{4}(\pi+R)}\left\{h B_{3}+\theta B_{4} T(\pi+R)+M L_{Z} B_{3}\right\} \\
& F=\frac{1}{\theta \cdot B_{4}(\pi+R)}\left\{h B_{3}+M L_{X} B_{2}\left(e^{-\theta t_{2}}-e^{-\theta t_{1}}\right)\right. \\
& +M L_{Y} B_{3}\left(e^{-\theta t_{3}}-e^{-\theta t_{2}}\right) \\
& \left.+M L_{Z} B_{3} e^{-\theta t_{3}}\right\} \\
& U=\ln \frac{E}{F} \\
& \text { Maka } \\
& T_{r}^{*}=E-F e^{\theta T_{r}} \\
& \text { Maka persamaan (41) dapat dituliskan sebagai } \\
& U=\ln T_{r}^{*}+\theta T_{r}
\end{aligned}
$$

\section{Tahap Penyelesaian Model}

Tahapan penyelesaian model mengikuti langkahlangkah sebagai berikut: 
- Menentukan profit margin setelah diberlakukan discount berdasarkan perlakuan discount yang digunakan, dengan persamaan (25, 26, dan 27);

- Menentukan saat retur optimal dilakukan, $T_{r}^{*}$ menggunakan persamaan (42) dengan cara trial error;

- Menentukan kuantitas pemesanan optimal, $Q^{*}$, menggunakan persamaan (40);

- Menghitung total biaya persediaan per tahun menggunakan persamaan (37).

\section{Hasil dan Pembahasan}

Contoh perhitungan numerik yang digunakan untuk mengilustrasikan algoritma penyelesaian model, mempertimbangkan tiga jenis produk. Diskon yang diberikan terdiri dari 3 tahap perlakuan sehingga mengakibatkan profit margin yang hilang dari masing-masing produk sebesar $x \%, y \%$, dan $z \%$. Berikutdata lainnya dapat dilihat pada Tabel 1.

Pemasok memberikan kesempatan retur untuk produk yang mendekati kadaluwarsa sekurangkurangnya selama $\left(T-T_{r}\right)$ sebelum tanggal kadaluwarsa dengan konsekuensi charge per unit sebesar $2,5 \%$ dari harga produk yang diretur.

Hasil perhitungan yang diperoleh dari kasus di atas adalah waktu retur optimal, $T_{r}^{*}=17,71$ minggu dengan kuantitas produk yang diretur, $Q_{r}=$ 158 unit, kuantitas pemesanan optimal, $Q^{*}=$ 11,024 unit, dengan total biaya persediaan yang ditimbulkan per tahun sebesar Rp 398.719.998.

Analisis sensitivitas terhadap model yang dikembangkan tersebut dilakukan dengan merubah (menambah atau mengurangi) beberapa nilai parameter

Tabel 1. Data-data produk

\begin{tabular}{lr}
\hline Keterangan & Produk \\
\hline$T$, minggu & 24 \\
$t_{1}$, minggu & 13 \\
$t_{2}$, minggu & 15 \\
$t_{3}$, minggu & 17 \\
$B_{0}$, unit & 150 \\
$B_{1}$, unit & 250 \\
$B_{2}$, unit & 260 \\
$B_{3}$, unit & 290 \\
$B_{4}$, unit & 250 \\
$P$, Rp/unit & 14.500 \\
$A$, Rp/sekali pesan & 10.000 \\
$A_{r}$, Rp/sekali retur & 10.000 \\
$a$, Rp/unit & 16.100 \\
$h$, Rp/unit/tahun & 400 \\
$\pi$, Rp/unit & 700 \\
$\theta$ & 0,12 \\
$x \%$ & 12 \\
$y \%$ & 19 \\
$z \%$ & 28 \\
\hline
\end{tabular}

yang ada sebesar $-25 \%$ hingga $+25 \%$. Hal tersebut untuk melihat efek yang akan terjadi dari adanya perubahan terhadap nilai parameter-parameter tersebut di dalam total biaya persediaan.

Parameter-parameter yang digunakan untuk melakukan analisis sensitivitas ini dapat dilihat pada Tabel 2. Ternyata dengan adanya perubahan parameter- parameter $t_{1}, t_{2}, t_{3}, P, A, h, a, A_{r}, R, \pi, x, y$, $z$, nilai variabel keputusan $T_{r}^{*}$ dan total biaya persediaan tidak terlalu berubah secara signifikan. Namun pada perubahan nilai $T, B_{0}, B_{1}, B_{3}, B_{4}$, dan $\theta$ perubahannya cukup signifikan terhadap nilai $Q$ maupun total biaya persediaan, sehingga dikatakan bahwa model sensitif terhadap adanya perubahan tersebut, solusinya adalah model harus mengalami perubahan untuk mengakomodir perubahan pada parameter-parameter tersebut.

\section{Simpulan}

Pada makalah ini telah dikembangkan suatu model persediaan untuk produk yang mendekati masa kadaluwarsa dengan mempertimbangkan diskon penjualan tiga tahap, dimana semakin mendekati tanggal kadaluwarsa diskon penjualan yang diberikan akan semakin besar selain itu juga mempertimbangkan adanya retur. Adapun laju permintaan yang dipertimbangkan berupa trapezoidal type demand rate. Melalui model ini pihak ritel dapat melihat posisi persediaan ketika diskon diberikan pada setiap tahapan diskon, setelah periode diskon terlebih dahulu ditetapkan. Selain itu, pihak ritel juga dapat menentukan kapan sebaiknya retur dilakukan, berapa jumlah produk yang diretur, dan berapa jumlah pemesanan yang optimal agar total biaya persediaan per periode yang ditimbulkan minimum. Namun demikian, pihak ritel harus cermat dalam mengidentifikasi laju deteriorasi produk $(\theta)$ dan rentang waktu mulai produk datang hingga produk mengalami kadaluwarsa $(T)$, karena performansi model yang dihasilkan sangat sensitif terhadap nilai-nilai tersebut.

Model ini merupakan model sederhana dari kondisi riil di Mirota Kampus Swalayan yang masih menggunakan banyak asumsi. Sehingga dalam model ini masih banyak kelemahannya. Pengembangan untuk penelitian lanjutan dapat mempertimbangkan beberapa aspek, diantaranya adalah bahwa laju permintaan meningkat pada saat diskon diberikan dan merupakan fungsi harga. Selain itu, perlu dipertimbangkan pula untuk kasus multi item dengan masa kadaluwarsa yang berbeda-beda. Model juga akan semakin dinamis ketika periode diskon, yaitu kapan diskon dimulai dan berapa lama interval diskon diberikan, serta besarnya diskon di setiap tahap dijadikan sebagai variabel keputusan. 
Tabel 2. Rekapitulasi perhitungan analisis sensitivitas

\begin{tabular}{|c|c|c|c|c|c|}
\hline Parameter & $\begin{array}{c}\% \\
\text { Perubahan }\end{array}$ & $\begin{array}{c}T_{r}^{*} \\
\text { minggu }\end{array}$ & $\begin{array}{c}Q^{*} \\
\text { Unit }\end{array}$ & $\begin{array}{c}\text { TC } \\
\text { Rp/tahun }\end{array}$ & $\begin{array}{c}\% \\
\text { Perubahan TC }\end{array}$ \\
\hline \multirow{4}{*}{$T$} & +25 & 20,4535 & 18.100 & 1.020 .484 .005 & $-156,94263$ \\
\hline & +10 & 18,8529 & 13.684 & 604.201 .270 & $-52,12885$ \\
\hline & -10 & 16,4330 & 8.429 & 283.984 .646 & $+39,82723$ \\
\hline & -25 & 14,3769 & 5.018 & $\begin{array}{r}79.163 .324 \\
\end{array}$ & $+80,06785$ \\
\hline \multirow{4}{*}{$t_{1}$} & +25 & 17,5776 & 8.780 & 306.305 .405 & $+22,2876$ \\
\hline & +10 & 17,6374 & 10.160 & 322.832 .703 & $+8,64414$ \\
\hline & -10 & 17,7437 & 11.687 & 430.043 .721 & $-8,27858$ \\
\hline & -25 & 17,8510 & 12.685 & 479.174 .290 & $-20,64839$ \\
\hline \multirow{4}{*}{$t_{2}$} & +25 & 17,6126 & 10.478 & 378.916 .479 & 4,59449 \\
\hline & +10 & 17,6526 & 10.771 & 389.546 .045 & 1,91813 \\
\hline & -10 & 17,7270 & 11.152 & 405.710 .382 & $-2,15181$ \\
\hline & -25 & 17,8041 & 11.460 & 421.404 .066 & $-6,10325$ \\
\hline \multirow{4}{*}{$t_{3}$} & +25 & 18,0664 & 10.718 & 370.926 .325 & 6,60629 \\
\hline & +10 & 17,8587 & 10.990 & 390.436 .312 & 1,69397 \\
\hline & -10 & 17,4821 & 10.775 & 400.002 .340 & $-0,71461$ \\
\hline & -25 & 17,1060 & 10.226 & 398.921 .459 & $-0,44246$ \\
\hline \multirow{4}{*}{$B_{0}$} & +25 & 17,6864 & 6.193 & 415.348 .456 & $+70,95698$ \\
\hline & +10 & 17,6864 & 5.488 & 393.637.377 & $+76,42351$ \\
\hline & -10 & 17,6864 & 4.549 & 384.689 .271 & $+83,71221$ \\
\hline & -25 & 17,6864 & 3.844 & 362.978 .192 & $+89,17873$ \\
\hline \multirow{4}{*}{$B_{1}$} & +25 & 17,6864 & 5.691 & 100.108 .393 & $+74,79420$ \\
\hline & +10 & 17,6864 & 5.287 & 87.541 .351 & $+77,95839$ \\
\hline & -10 & 17,6864 & 4.750 & 70.785 .296 & $+82,17732$ \\
\hline & -25 & 17,6864 & 4.346 & $58.218,255$ & $+85,34151$ \\
\hline \multirow{4}{*}{$B_{2}$} & +25 & 17,7030 & 11.894 & 435.953 .985 & $-9,76418$ \\
\hline & +10 & 17,6936 & 11.335 & 412.710 .589 & $-3,91436$ \\
\hline & -10 & 17,6790 & 10.585 & 381.608 .274 & $+3,91673$ \\
\hline & -25 & 17,6680 & 10.022 & 358.288 .002 & $+9,78843$ \\
\hline \multirow{4}{*}{$B_{3}$} & +25 & 16.9310 & 8.095 & 264.583 .249 & $+33,38189$ \\
\hline & +10 & 17.3595 & 9.295 & 322.408 .766 & $+18,82229$ \\
\hline & -10 & 17.9999 & 10.687 & 391.772 .826 & $+1,35746$ \\
\hline & -25 & 18,5750 & 11.598 & 437.917.051 & $-10,26097$ \\
\hline \multirow{4}{*}{$B_{4}$} & +25 & 18,3570 & 11.578 & 420.072 .826 & $-6,77520$ \\
\hline & +10 & 17,9688 & 10.687 & 386.258 .820 & $+2,74580$ \\
\hline & -10 & 17,3291 & 9.302 & 277.995 .513 & $+30,171988$ \\
\hline & -25 & 16,7278 & 8.093 & 327.331 .830 & $\begin{array}{r}+17,41563 \\
\end{array}$ \\
\hline \multirow{4}{*}{$\theta$} & +25 & 16,1849 & 9.834 & 345.999 .106 & $+12,88259$ \\
\hline & +10 & 16,8677 & 9.636 & 338.409 .697 & $+14,79349$ \\
\hline & -10 & 17,7903 & 8.841 & 313.104 .506 & $+21,16496$ \\
\hline & -25 & 18,4726 & 7.982 & 281.574.378 & $+29,10378$ \\
\hline \multirow{4}{*}{$A$} & +25 & 17,6864 & 10.960 & 397.164 .256 & $-0,00003$ \\
\hline & +10 & 17,6864 & 10.960 & 397.164 .193 & $-0,00001$ \\
\hline & -10 & 17,6864 & 10.960 & 397.164 .110 & $+0,00001$ \\
\hline & -25 & 17,6864 & 10.960 & 397.164 .047 & $+0,00003$ \\
\hline \multirow{4}{*}{$A_{r}$} & +25 & 17,6864 & 10.960 & 397.164 .256 & $-0,00003$ \\
\hline & +10 & 17,6864 & 10.960 & 397.164 .193 & $-0,00001$ \\
\hline & -10 & 17,6864 & 10.960 & 397.164 .110 & $+0,00001$ \\
\hline & -25 & 17,6864 & 10.960 & 397.164 .047 & $+0,00003$ \\
\hline \multirow{4}{*}{$h$} & +25 & 16,9239 & 9.005 & 410.911 .483 & $-3,46137$ \\
\hline & +10 & 17,3661 & 10.119 & 404.005 .028 & $-1,72243$ \\
\hline & -10 & 18,0279 & 11.890 & 388.060 .794 & $+2,29209$ \\
\hline & -25 & 18,5969 & 13.518 & 370.025 .418 & $+6,83313$ \\
\hline \multirow{4}{*}{$R$} & +25 & 18,2794 & 12.597 & 439.505 .902 & $-10,67361$ \\
\hline & +10 & 17,9401 & 11.648 & 414.496 .574 & $-4,36405$ \\
\hline & -10 & 17,4081 & 10.228 & 379.496 .405 & $+4,44847$ \\
\hline & -25 & 16,9220 & 10.020 & 351.913.114 & $+11,39354$ \\
\hline \multirow{4}{*}{$P$} & +25 & 18,0595 & 11.978 & 397.916 .124 & $-0,18934$ \\
\hline & +10 & 17,8340 & 11.358 & 398.271 .462 & $-0,27880$ \\
\hline & -10 & 17,5370 & 10.564 & 394.880 .284 & $+0,57504$ \\
\hline & -25 & 17,3080 & 10.370 & 389.397 .900 & $+1,95543$ \\
\hline
\end{tabular}


Tabel 2. Rekapitulasi perhitungan analisis sensitivitas (lanjutan)

\begin{tabular}{cccccc}
\hline Parameter & $\%$ & $T_{r}^{*}$ & $Q^{*}$ & TC & $\%$ \\
& Perubahan & minggu & Unit & Rp/tahun & Perubahan TC \\
\hline \multirow{4}{*}{$a$} & +25 & 17,9774 & 11.750 & 445.765 .953 & $-12,23721$ \\
& +10 & 17,8100 & 11,293 & 415.886 .898 & $-4,71411$ \\
& -10 & 17,5490 & 10.596 & 379.308 .331 & $+4,49583$ \\
$\pi$ & -25 & 17,3150 & 10.388 & 354.464 .687 & $+10,75109$ \\
\hline & +25 & 17,8120 & 11.298 & 425.664 .919 & $-7,17607$ \\
& +10 & 17,7373 & 11.097 & 408.768 .986 & $-2,92192$ \\
& -10 & 17,6340 & 10.821 & 385.235 .535 & $+3,00344$ \\
& -25 & 17,5544 & 10.610 & 366.837 .405 & $+7,63582$ \\
\hline \multirow{2}{*}{$x$} & +25 & 17,7047 & 11.009 & 399.763 .837 & $-0,65456$ \\
& +10 & 17,6937 & 10.980 & 398.199 .915 & $-0,26079$ \\
& -10 & 17,6789 & 10.940 & 396.119 .013 & $+0,26315$ \\
& -25 & 17,6680 & 10.911 & 394.581 .195 & $+0,65035$ \\
\hline \multirow{2}{*}{$z$} & +25 & 17,7118 & 11.028 & 399.797 .888 & $-0,66313$ \\
& +10 & 17,6966 & 10.988 & 398.214 .911 & $-0,26457$ \\
& -10 & 17,6762 & 10.933 & 396.120 .590 & $+0,26275$ \\
& -25 & 17,6612 & 10.893 & 394.588 .097 & $+0,64861$ \\
\hline
\end{tabular}

\section{Daftar Pustaka}

1. Bahagia, S. N., Sistem Inventori, Penerbit ITB, Bandung, 2006.

2. Indrianti, N., Ming T., dan Toha, I. S., Model Perencanaan Kebutuhan Bahan dengan Mempertimbangkan Waktu Kadaluwarsa Bahan, Jurnal Media Teknik, 2, Yogyakarta, 2001, pp. 60-65.

3. Nafisah, L., Puryani, A., dan Lukito, F. X. K. B., Model Persediaan Single Item dengan Mempertimbangkan Tingkat Kadaluwarsa dan Pengembalian Produk, Prosiding Seminar Nasional Manajemen Teknologi XIV, Program Studi Magister Manajemen Teknologi Program, Pasca Sarjana, Institut Teknologi Sepuluh Nopember, 2011, pp. A.6.1-A.6.12.

4. Singh, T. and Sahu, K., An Inventory Model for Deteriorating Items with Different Constant Demand Rates, African Journal of Mathematics and Computer Science Research, 5(9), 2012, pp. 158-168.

5. Karmakar, B., and Choudhury, K. D., A Review on Inventory Models for Deteriorating Items with Shortages, Assam University Journal of Science \& Technology: Physical Sciences and Technology, 6(2), 2010, pp. 51-59.

6. Prasetyo, H., Munawir, H., dan Musthofiyah, Ning A., Pengembangan Model Persediaan dengan Mempertimbangkan Waktu Kedalu- warsa Bahan dan Faktor Incremental Discount, Jurnal Ilmiah Teknik Industri, 4(2), 2005, pp. 49-56.

7. Prasetyo, H., Nugroho, M. T., dan Pujiarti, A., Pengembangan Model Persediaan Bahan Baku dengan Mempertimbangkan Waktu Kadaluwarsa dan Faktor Unit Diskon, Jurnal Ilmiah Teknik Industri, 4(3), 2006, 108-115.

8. Limansyah, T., dan Lesmono, D., Model Persediaan Multi Item dengan Mempertimbangkan Faktor Kadaluwarsa dan Faktor All Unit Discount, Jurnal Teknik Industri, 13(2), 2011, pp. 87-94.

9. Jaya, S. S., Octavia, T., dan Widyadana, I. G. A., Model Persediaan Bahan Baku Multi Item dengan Mempertimbangkan Masa Kadaluwarsa, Unit Diskon, dan Permintaan yang Tidak Konstan, Jurnal Teknik Industri, 14(2), 2012, pp. 97-105.

10. Bramorski, T., Determining Discounts for Perishable Inventory, Journal of Bussiness \& Economics Research, 6(1), 2008, pp. 51-58.

11. Widyadana, G. A. and Wee, H. M., A Replenishment Policy For Item with Price Dependent Demand And Deteriorating Under Markdown Policy, Jurnal Teknik Industri, 9(2), 2007, pp. 75-84.

12. Jayashree, P. R., Deteriorating Inventory Model for Pharmaceutical Goods with Variable Holding Cost, International Journal of Business Management, 3(2), 2013, pp. 89-100. 